\title{
Pulmonary pathology in AIDS: atypical Pneumocystis carinii infection and lymphoid interstitial pneumonia
}

University of Miam School of Medicine and Mount Sinai Medical Center, Miami Beach, Florida USA

M J Saldana

University of Miam School of Medicine and Parkway Regional Medical Center,

Miami, Florida, USA

$\mathrm{J}$ M Mones

Reprint requests to:

Dr M J Saldana,

Department of Pathology and Laboratory Medicine, Blum Building, 2nd Floor, Mount Sinai Medical Center, 4300 Acton Road, Miami Beach, Florida 33140, USA.

\author{
Mario J Saldana, Joan M Mones
}

It is generally agreed that the acquired immunodeficiency syndrome (AIDS) results from infection by the human immunodeficiency virus (HIV). The latter agent destroys primarily $\mathrm{T}$ helper lymphocytes and produces a progressive impairment of cell mediated immunity with increased susceptibility to various opportunistic infections and malignant tumours. ${ }^{12}$ The accepted definition of AIDS, $^{3}$ as of 1 January 1993, includes all HIV-infected individuals with severe immunosuppression that is, less than $200 \times 10^{6} / 1 \mathrm{CD} 4+\mathrm{T}$ lymphocytes, or a percentage of $\mathrm{CD} 4+\mathrm{T}$ lymphocytes below $14 \%$ of the total count of lymphocytes. The definition also includes the presence of tuberculosis, recurrent pneumonia, or invasive cervical cancer.

The lung is a major target of disease and the cause of death in most patients with AIDS. About $80 \%$ of children infected with AIDS develop pulmonary problems and, if left untreated, $70 \%$ will die within two years of diagnosis. ${ }^{4}$

The purpose of this paper is to review and illustrate two lesser known areas of pulmonary disease in AIDS, namely (1) atypical Pneumocystis carinii infection; and (2) lymphoid interstitial pneumonia.

\section{Atypical Pneumocystis carinii pneumonia}

Over the years the taxonomy of Pneumocystis carinii has been a matter of controversy. How-

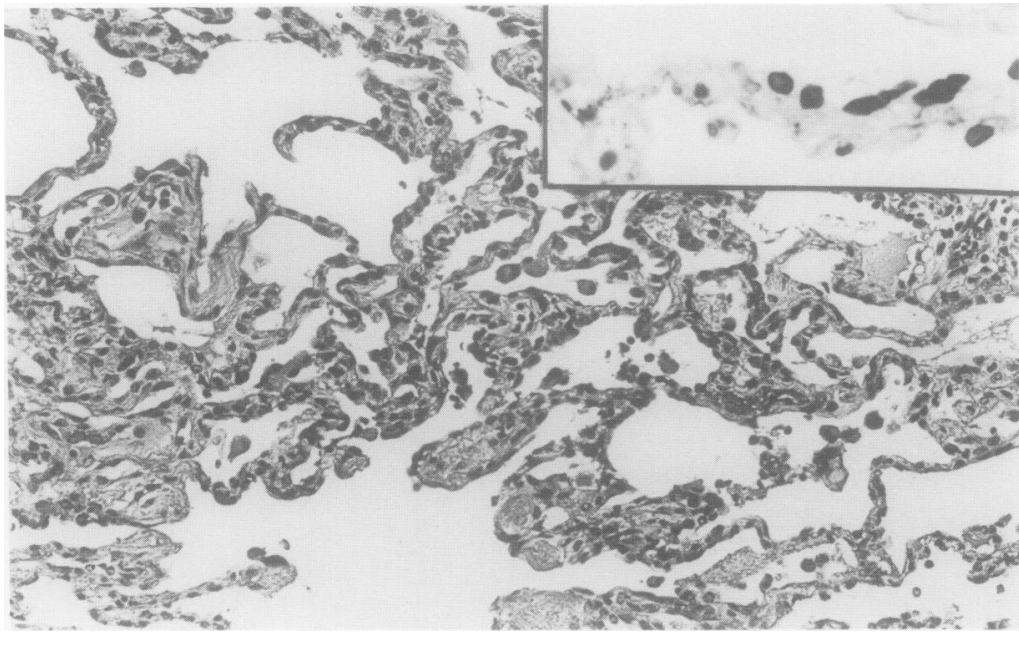

Figure 1 Grade I ("incipient") PCP with empty alveolar spaces and mild interstitial thickening by inflammatory cells. The inset shows septal attachment of Pn carinii. Stain: haematoxylin and eosin, original magnification $\times 400$ reduced to $64 \%$ in origination; inset Gomori's methenamine silver (GMS), original magnification $\times 400$. Reproduced from ref 12 with permission. ever, recent evidence using RNA probes and Southern blot analysis indicates that it is probably a fungus with a unique unicellular mycelial phase. ${ }^{5}$ Vanek and Jirovec ${ }^{6}$ in 1952 identified $P n$ carinii as the agent in outbreaks of pneumonia in malnourished infants and children in European orphanages after World War II. It has since become a well recognised pathogen in patients immunocompromised by malignancies, prolonged corticosteroid therapy, and organ transplantation.

The incidence of Pneumocystis carinii pneumonia (PCP) has risen dramatically in developed nations since the advent of AIDS. It is often the initial presentation of the disease and will affect eventually $60-80 \%$ of these patients. ${ }^{7}$ The risk of developing PCP in HIV positive adults increases significantly as the CD4 (helper) $\mathrm{T}$ lymphocyte count falls below $200 \times 10^{6} / 1 .^{8}$

The prognosis of PCP in children is much poorer than in adults, and the initial infection is often fatal even though their CD4 T lymphocyte count may be higher. ${ }^{9}$ PCP is relatively rare in Africa and has not been reported in Uganda, a country with the highest number of AIDS patients in the world. This surprising finding is probably due to the fact that $P n$ carinii is not indigenous to that part of the world. ${ }^{10}$

The typical patient with PCP develops fever, cough, and shortness of breath. The chest radiograph varies considerably from normal, to relatively mild involvement with interstitial or reticulonodular infiltrates throughout both lungs, to more severe disease with patchy areas of alveolar consolidation. When the alveolar disease becomes extensive and confluent there is respiratory insufficiency, frequently followed by death of the patient. The duration of symptoms of PCP is longer in patients with AIDS than in non-AIDS patients, and the clinical manifestations are somewhat different in the two groups. ${ }^{11}$

The pathological manifestation of early ("incipient") PCP is characterised by empty alveoli; ${ }^{12}$ however, with special stains individual cysts and trophozoites can be seen attached to the alveolar septae (fig. 1). As the infection proceeds the alveoli become progressively filled by masses of exudative material with a characteristic "foamy" or "honeycomb" appearance. Ultrastructurally, the "foamy" exudates of $P n$ carinii consist of large numbers of trophozoites with their microtubular extensions, the parasite cysts, fibrin, and cellular debris. ${ }^{13}$ The trophozoites are well demonstrated with Romanovsky type stains such as 
Giemsa, Wright-Giemsa and Diffquick. The cytoplasm appears blue and the nucleus red surrounded by a pale halo. The cysts are best demonstrated by Grocott's modification of Gomori's methenamine silver (GMS) stain. Cysts and trophozoites can be stained in the same preparation with AFIP light silver/haematoxylin and eosin stain, and Shiota's combined GMS/Giemsa method. ${ }^{14}$

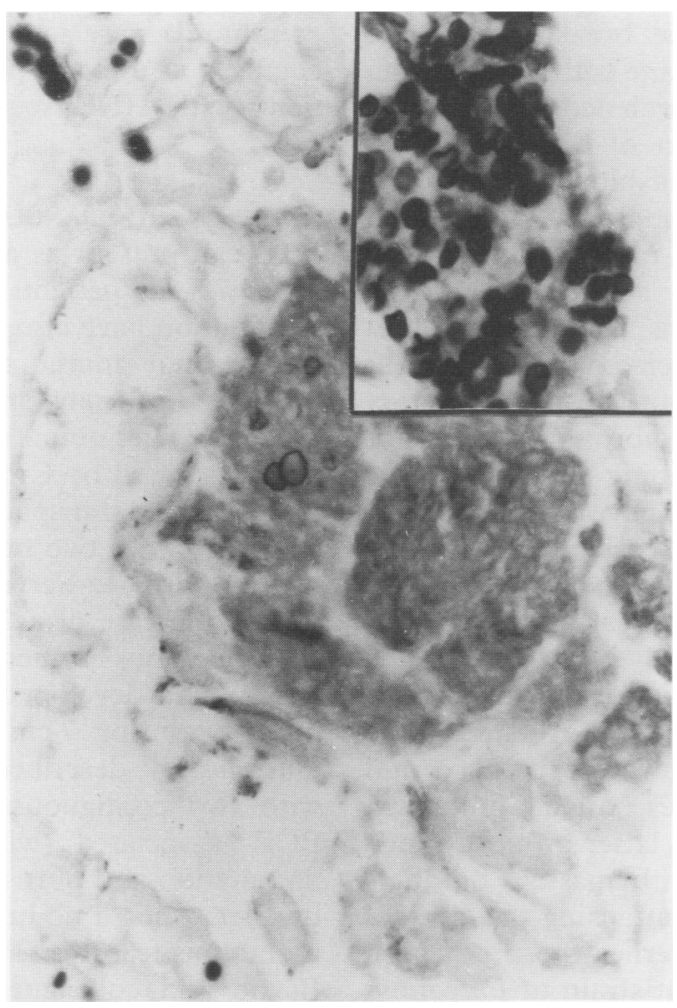

Figure 2 Effects of treatment on PCP showing an intraalveolar mass of exudate with few discernible cysts as a result of treatment for less than one week. The inset shows pretreatment biopsy for comparison. Stain: haemotoxylin and eosin, original magnification $\times 1000$ reduced to $64 \%$ in origination; inset GMS original magnification $\times 1000$. Reproduced from ref 15 with permission.
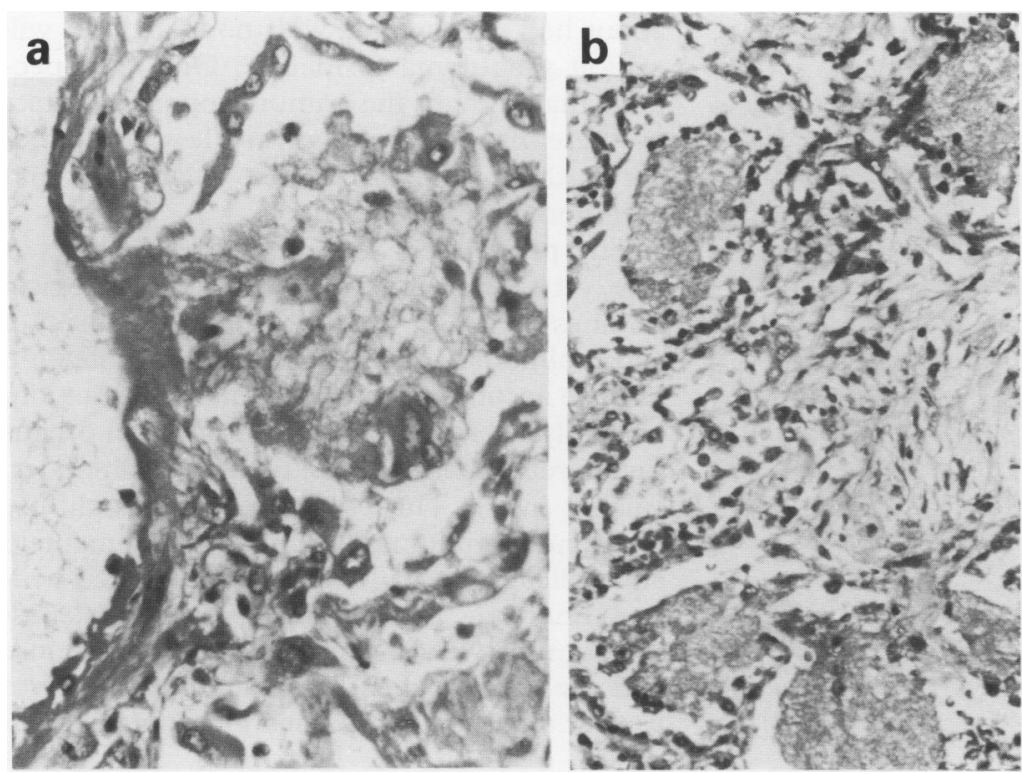

Figure 3 Diffuse alveolar damage in PCP. (a) "Exudative" stage of diffuse alveolar drainage including the presence of hyaline membranes, during the first week of treatment; (b) "proliferative" stage of diffuse alveolar drainage during second week of the disease characterised by intra-alveolar fibroblastic proliferation. Stain: haematoxylin and eosin. Original magnification $\times 400$ (a) and $\times 250$ (b), reduced to $74 \%$ in origination.
We have studied the pulmonary pathology in AIDS patients with severe PCP requiring assisted ventilation. ${ }^{15}$ Patients dying within the first two weeks on the respirator had heavy lungs, usually more than $2000 \mathrm{~g}$ in combined weight. The pleura was frequently smooth and shiny. On cut section the lungs were airless, pale grey, and frequently slimy in consistency. Microscopically there was extensive filling of alveoli with proteinaceous exudate (fig 2). Eight patients dying within one week on the respirator had the "exudative" stage of "diffuse alveolar damage" including hyaline membranes and reactive, atypical alveolar lining cells (fig 3a). In nine patients surviving more than one week changes of "proliferative" diffuse alveolar damage were observed, including the presence of intra-alveolar fibroblastic proliferation extending to alveolar ducts and bronchioli (fig $3 b$ ). Eleven cases of PCP of a relatively lesser severity responded to treatment but recurrence of the infection on two, three or more occasions was noted in the following months or years; some patients died of other causes.

With the large number of cases of PCP seen in the AIDS epidemic it has been possible to appreciate several atypical manifestations of this infection and these include: (1) interstitial lung disease; (2) lymphoplasmacytic interstitial infiltrates; (3) nodular and granulomatous PCP; (4) cavitary PCP; and (5) extrapulmonary PCP.

\section{INTERSTITIAL LUNG DISEASE}

Diffuse alveolar damage is a well recognised, non-specific reaction of alveolar tissue to several injurious agents of a physical, chemical, and biological nature. The development of diffuse alveolar damage in PCP has been the subject of several studies. ${ }^{16-23}$ In the study by Nash and Fligiel ${ }^{19} 15$ of 17 homosexual males (88\%) studied at post mortem examination had PCP. Of these 15 patients $12(71 \%)$ had manifestations of diffuse alveolar damage in the "exudative" and "proliferative" stages. These investigators showed that, while cytomegalovirus (CMV) infection or Pn carinii may be the cause of diffuse alveolar damage, the contribution of other factors such as oxygen toxicity could not be excluded. This is a problem inherent to post mortem studies; it is only when PCP is diagnosed by biopsy and before oxygen administration that a direct relationship between $P_{n}$ carinii and diffuse alveolar damage can be ascertained. In a study by Ramaswany et $a l^{23}$ diffuse alveolar damage was described in 12 patients with no concurrent infections in the lung biopsy sample; however, some of these patients were receiving treatment for PCP, including oxygen administration.

The mechanisms by which $P n$ carinii produces diffuse alveolar damage are not clear, although considerable insight has been gained from studies in both humans and animals. Price and Hughes ${ }^{24}$ described the early stages of PCP, with no clinical manifestations (infestation) and noted that the cysts first attach to the inner lining of the alveolus. In rats developing PCP after the administration of cortisone acetate, 
Barton and Campbell, ${ }^{25}$ and Lanken $e a^{26}$ also described the attachment of trophozoites to type I pneumocytes. The latter eventually died, leaving a gap in the epithelial lining of the alveolus which was soon repaired by proliferating type II pneumocytes. Observations of the $P n$ carinii cycle in vitro corroborated that trophozoites initially attach to type I pneumocytes and later evolve into cyst forms. After the cysts were released the host cells underwent degeneration and death. ${ }^{27}$

It is probable that the breakdown of the alveolar capillary membrane is the mechanism of production of protein-rich oedema fluid that underlies the production of diffuse alveolar damage. Damage to the air-blood barrier probably allows irritants, chemotactic factors, and fibrogenic substances to reach the interstitial space.

Lesions of bronchiolitis obliterans are frequently seen in PCP associated diffuse alveolar damage and may contribute to the respiratory insufficiency. Interstitial fibrosis ("mural" or "septal") and "honeycombing" as the end stage of diffuse alveolar damage have been described, but they are rare in our experience because most of these patients either recover completely or die before such changes can occur. ${ }^{2829}$

Why most patients with PCP develop the "classic" form of the infection with characteristic intra-alveolar foamy exudates while others develop diffuse alveolar damage and other interstitial responses remains unknown. It is possible that in the latter group a much more severe infection with massive numbers of trophozoites diffusely attacking the alveolar capillary membrane underlies the production of the lesions. A different strain of Pn carinii, or an idiosyncratic host response, are also possibilities to be considered.

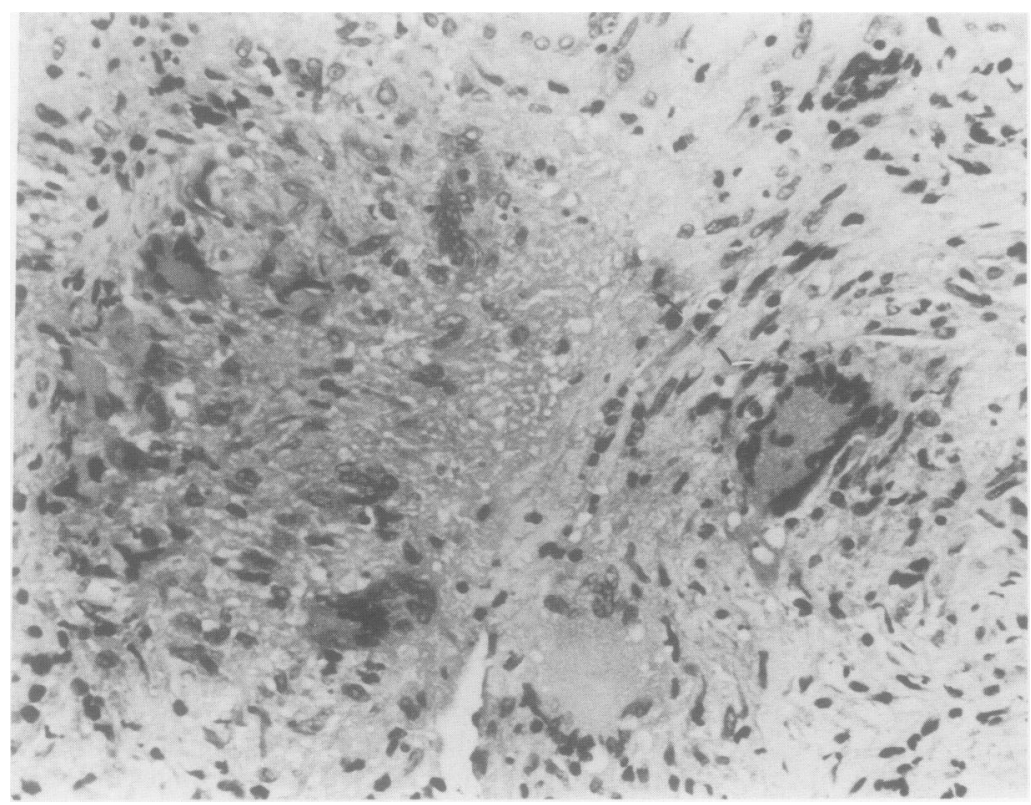

Figure 4 Granulomatous PCP mimicking tuberculosis. The centre of the granuloma contains the foamy exudate characteristic of PCP and later confirmed by silver stain. Stain: haematoxylin and eosin, original magnification $\times 200$ reduced to $90 \%$ in origination.

\section{LYMPHOPLASMACYTIC INTERSTITIAL}

\section{INFILTRATES}

Pneumocystis carinii may also produce a significant lymphoplasmacytic interstitial infiltrate more striking in children than adults. It is of historical interest that, because of this feature, the disease was originally termed "lymphoid interstitial pneumonia" in $1952 .{ }^{6}$ The same designation, however, was later used by Liebow and Carrington ${ }^{3031}$ in a totally different context. Ironically, a true form of lymphoid interstitial pneumonia unrelated to PCP has become recognised as a major pulmonary process in patients with AIDS (see later).

\section{NODULAR AND GRANULOMATOUS PCP}

PCP can present as a localised process in up to $33.7 \%$ of patients. ${ }^{32}$ Unilateral and lobar distribution have also been reported, ${ }^{33}$ and the disease may mimic tuberculosis. ${ }^{34}$ Less frequently PCP may present as a nodule simulating a carcinoma or a granuloma. In the case described by Cross and Steigbigel ${ }^{35}$ a 28 year old renal transplant patient on prednisone presented with two nodules in the right lower lobe. Rodriguez-Servera and colleagues ${ }^{36}$ reported the case of a 28 year old woman with systemic lupus erythematosus, treated with cytoxan, who developed two masses in the left lung measuring $7 \mathrm{~cm}$ and $3 \mathrm{~cm}$ in diameter. Hartz et $a l^{37}$ described a 57 year old woman with two contiguous nodules of necrotising PCP associated with granulomatous inflammation and fibrosis. In the case described by Bier $e t a l^{38}$ a nodular lesion also had granulomatous features. Two patients described by Barrio and colleagues ${ }^{39}$ had nodular lesions of PCP, in one case associated with central cavitation. Two other patients exhibiting nodular lesions with granulomatous features were reported by Bleiweiss et al, ${ }^{40}$ but a third patient with granulomatous features had bilateral and diffuse PCP.

Based on the above information it seems that about half the patients with nodular PCP will exhibit granuloma formation. One can speculate that perhaps the immunosuppressed state of these patients is relatively less profound, hence their ability to mount a localised and granulomatous response.

The presence of granulomatous features is rare, yet it is one of the most striking histological findings in PCP (fig 4). ${ }^{40-42}$ Many cases of extrapulmonary spread of $P n$ carinii infection are also accompanied by granuloma formation, probably because such lesions occur in organs rich in reticuloendothelial tissue (lymph nodes, spleen, liver). The two patients with diffuse PCP and granulomas described by Blumenfeld and colleagues ${ }^{42}$ had received aerosolised pentamidine and zidovudine, so a possible association between the granulomatous response and the inhaled agent (pentamidine) deserves further attention. Ill defined granulomas composed of scattered histiocytes and multinucleated giant cells of foreign body type represent peculiar variations in the spectrum of histiocytic granulomatous responses. They are often seen in treated patients and in 


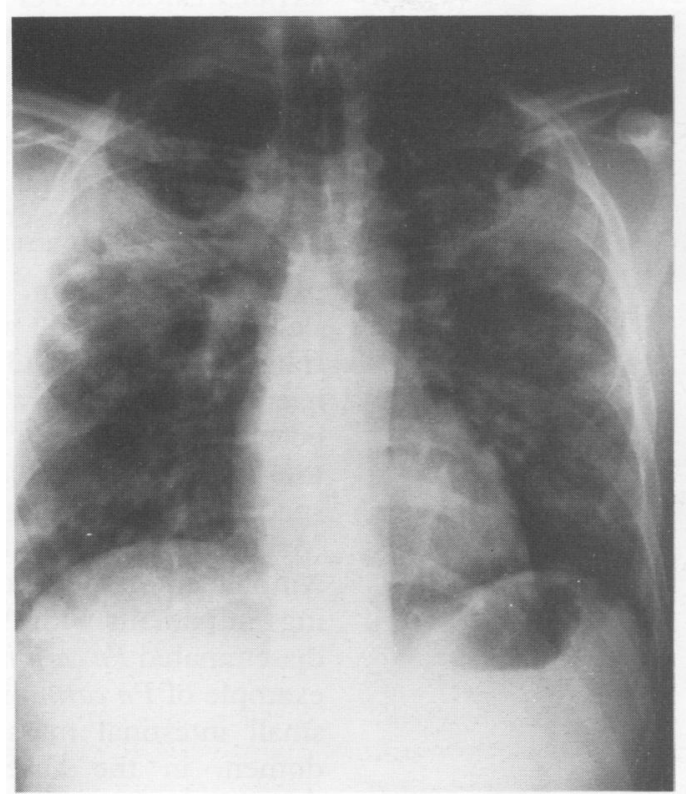

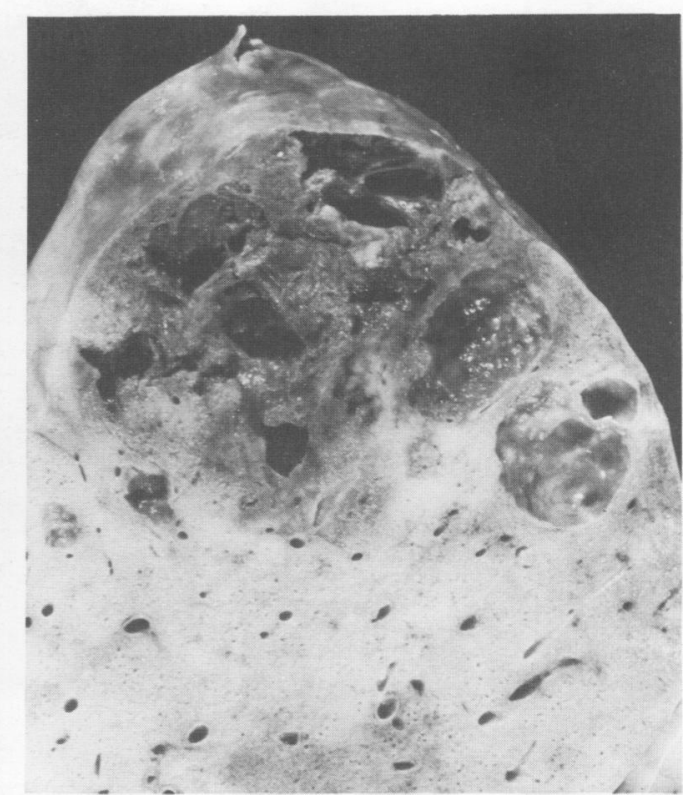

Figure 5 (a) Chest radiograph of a 32 year old homosexual male with bilateral, confluent reticulonodular infiltrates and extensive cavitation of both apices. (b) Section of the lung at post mortem examination showing extensive cavitation at the left upper lobe lesion with surrounding PCP consolidation.

association with masses of degenerated and calcified PCP exudate.

\section{CAVITARY PCP}

For many years it was believed that $P n$ carinii was unable to elicit tissue necrosis in the lung but recently this has been contradicted. ${ }^{43-47}$ Five cases of PCP with cavitary lesions, some presenting with pneumothoraces, were described by Eng and colleagues. ${ }^{43}$ These investigators thought that the chronicity of PCP in AIDS patients was responsible for the accumulation of many activated macrophages with production of elastase and subsequent digestion of lung tissue. Mark ${ }^{44}$ and Liu $e t a l^{45}$ proposed that arterial invasion by the organisms leads to thrombosis and secondary necrosis and cavitation of lung tissue. Pneumocystis carinii could be identified within the vascular lumina, ${ }^{445}$ and the authors described severe necrotising vasculitis with lymphocytes, immunoblasts, and plasma cells. In 1989 we described a peculiar invasion of the pulmonary interstitium and pulmonary vessels by $P n$ carinii in a case of cavitary pneumonia (figs 5 and 6$).{ }^{46}$

Travis et $a l^{47}$ reviewed 123 lung biopsy specimens from 76 patients with PCP and reported one case of vascular invasion with associated vasculitis; several of their cases had intraparenchymal cysts probably representing cavitation with septal invasion. In a recent study Murry and Schmidt ${ }^{48}$ described tissue invasion in seven patients with AIDS and two with leukaemia. Invasion of $P_{n}$ carinii into the interstitial compartment was present in eight of their nine patients. Organisms were demonstrated in alveolar septa (eight cases), pleura (six cases), and vessel walls (two cases). Pulmonary cavitation occurred in seven of eight cases with tissue invasion, and six of these patients developed pneumothoraces. Ultrastructurally, both the tissue invasive and the intra-alveolar organisms were predominantly of the trophozoite form; they were present in greater numbers than suggested by the routine silver stain which detects only cysts. Immunocytochemical techniques which demonstrate both trophozoite and cyst forms were much more sensitive than silver stains for the detection of Pn carinii.

Murry and Schmidt ${ }^{48}$ addressed the problem of how tissue invasion causes necrosis in PCP. The possibility of a host inflammatory response was ruled out in view of the distinct paucity of inflammation in these cases. A second mechanism - direct tissue injury by toxins or hydrolytic enzymes which might be elaborated by the organism - cannot be accepted or rejected since so little is known about the biology of $P_{n}$ carinii. A third possibility - vascular invasion with secondary infarction - seems unlikely since six patients with cavitation in their study ${ }^{48}$ did not show vascular invasion and, when present, the latter was not quantitively sufficient to explain the extent of the necrosis. Nevertheless, the possibility of collapse of pulmonary capillaries within the distended alveolar septa producing ischaemia and necrosis is an attractive hypothesis to be explored further. ${ }^{48}$

The role of a coinfection in the cavitary phenomenon in patients with PCP also deserves attention since many of these patients do have mixed infections. As noted by Murry and Schmidt, ${ }^{48}$ however, the strongest evidence supporting a primary role for $P n$ carinii was that two patients with cavitation had no documented coinfections, and a third patient had cytomegalovirus isolated from the urine only. The possibility of a necrotising concomitant infection should, however, be carefully ruled out when examining cases of cavitary PCP. 

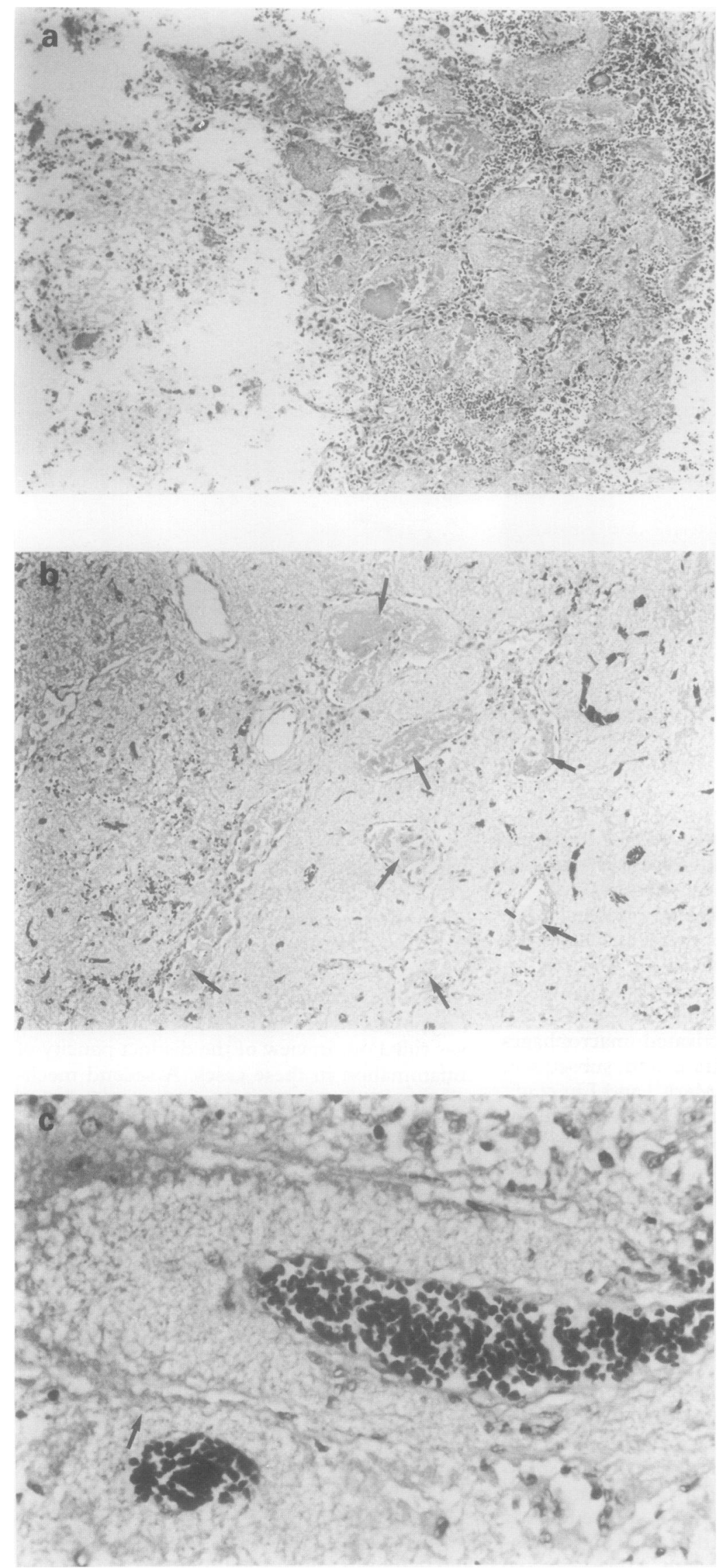

Figure 6 (a) Necrotising and cavitary PCP in a patient with AIDS. Cavitation is present next to solid pneumonic consolidation. (b) Tissue invasion in cavitary PCP. This peculiar microscopic appearance was seen adjacent to a cavity. There is diffuse and remarkable widening of the pulmonary interstitium. The alveoli are reduced in volume and can be recognised by a denser eosinophilic exudate surrounded by alveolar lining epithelium (arrows). (c) Intrusive exudate of Pn carinii has split the intima from the outer layers of this pulmonary vein (arrow) producing considerable occlusion of the lumen. Stain: haematoxylin and eosin. Original magnification $\times 120$ ( $a$ and $b$ ) and $\times 600(c)$ reduced to $63 \%$ in origination. Reproduced from ref 46 with permission.

\section{EXTRAPULMONARY PCP}

Extrapulmonary spread of $P$ n carinii infection does occur in patients without as well as with AIDS. ${ }^{49-58}$ Favoured sites of spread include the regional lymph nodes and other organs rich in reticuloendothelial tissue such as liver and spleen. Unusual presentations include polypoid lesions of the ear, ${ }^{5051}$ and spread to the hard palate, pericardium, and thymic capsule. ${ }^{52}$ Pavlica $^{53}$ reported a remarkable case of transplacental spread of the organism via haematogenous pathways. Eye involvement has been documented. ${ }^{54-56}$ Unger et $a l^{57}$ described the presence of $P n$ carinii in Virchow-Robin spaces surrounding cortical arterioles. Macher $^{56}$ believes that splenomegaly and lymphadenopathy, not infrequent clinical findings in patients with AIDS, may be caused by disseminated $P n$ carinii infection. A remarkable example of $P n$ carinii infection presenting as a small intestinal mass causing an acute abdomen, in the absence of pulmonary involvement, was reported by Carter et al. ${ }^{58}$ Regardless of location, the presence of Pn carinii in organs other than the lung can be recognised by the same characteristic eosinophilic "honeycomb" exudates.

\section{Lymphoid interstitial pneumonia}

Lymphoid interstitial pneumonia was described by Carrington and Liebow ${ }^{30}$ in an abstract, in 1966 , based on four adults and one child who exhibited massive lymphoid infiltrates of the lung, bilateral in four patients and unilateral in one. The definitive description, ${ }^{31}$ published seven years later, was based on 17 patients and appeared under the title "diffuse pulmonary lymphoreticular infiltrates associated with dysproteinaemia." This remarkable feature of the disease has since been corroborated by other investigators. ${ }^{59-69}$ We estimate that about $80 \%$ of patients with lymphoid interstitial pneumonia will present with dysgammaglobulinaemia.

Lymphoid interstitial pneumonia has been described in association with Sjögren's syndrome, ${ }^{70-72}$ primary biliary cirrhosis, ${ }^{73}$ pernicious anaemia and agammaglobulinaemia, ${ }^{74}$ chronic active hepatitis with renal tubular acidosis, ${ }^{75}$ and allogenic bone marrow transplantation. ${ }^{76}$ Familial occurrence has been described. ${ }^{77}$ Whether it represents an inflammatory ("reactive") process or a malignant lymphoma was a question already posed by Liebow and Carrington. ${ }^{3031}$ Observations over the past two decades indicate that most examples of lymphoid interstitial pneumonia are initially low grade lymphomas and later evolve into aggressive lymphomas in the lung and elsewhere. ${ }^{78-85}$ This transition may take many years. It might never become manifest in adult patients with short follow up studies. It is therefore convenient to state $^{86}$ that lymphoid interstitial pneumonia is best considered "a prelymphomatous state frequently associated with other features of immune dysregulation."

In 1983 we described a form of lymphoid interstitial pneumonia occurring almost exclusively among Haitian adults and children 
living in Miami, Florida, who also had HIV infection. ${ }^{8788}$ At about the time of the original description Oleske $e t a l^{89}$ and Rubinstein et $a l^{90}$ also noted the same process in their series of children with AIDS living in the north-eastern USA. Kradin and Mark, ${ }^{91}$ also in 1983, in their papers on benign lymphoid disorders of the lung included two Haitian adult patients with the same disease. Subsequent papers ${ }^{92-106}$ have described in greater detail the clinical manifestations, radiological features, and aetiopathogenesis of this pulmonary condition of HIV infected individuals.

Most of the adults in our study ${ }^{88}(81 \%)$ had HIV infection only at the time of diagnosis. Fifteen of these patients (43\%) progressed to AIDS during the course of their disease, while $20(57 \%)$ did not evolve into full blown AIDS. Only eight patients (19\%) had AIDS at diagnosis and remained so until death. By definition, all children in this study had AIDS.

Chest radiographs taken at the time of diagnosis and during the evolution of the disease were classified into four grades: 0 , normal chest radiograph; I, reticulonodular infiltrates with nodules up to $5 \mathrm{~mm}$ in diameter, frequently referred to as "miliary"; II, grade I plus one or more patchy areas of alveolar consolidation; III, one or more areas of alveolar consolidation and little or no interstitial component of significance ("atypical" lymphoid interstitial pneumonia). ${ }^{88}$ In adults grades I (39\%) and II (54\%) occurred most frequently. In children grade I was the most common pattern at presentation $(67 \%)$, to be superseded by grade II $(67 \%)$ at later stages of the disease.

Pathologically ${ }^{88}$ the mildest or earliest forms of lymphoid interstitial pneumonia represents hyperplasia of bronchial associated lymphoid tissue (BALT) with little interstitial involvement (fig 7). Aggregates of lymphocytes and plasma cells form around airways and blood vessels. As the disease progresses they extend along the alveolar septae (fig 8). In later stages large confluent nodules often measure up to $2.5 \mathrm{~cm}$ in diameter. The lung parenchyma in these areas is solid and resembles a lymph node. Lymphoid interstitial pneumonia has not been noted to progress to interstitial fibrosis of the lung in either children or adults; progression to Kaposi's sarcoma has been noted in adults only. In children it can be a debilitating disease producing respiratory insufficiency with severe hypoxaemia and digital clubbing. In adults it is usually asymptomatic but its radiographic features mimic PCP.

The composition of the lymphocytic population was studied in two children and one adult by monoclonal antibodies applied to frozen sections of the lesions. ${ }^{88}$ The results were comparable in all three cases and were characterised by: (1) positivity for both kappa and lambda light chains (polyclonality); (2) distinct predominance of T lymphocytes (CD5/Leu5) over B lymphocytes (CD22/Leu4); and (3) T suppressor lymphocytes (CD8/Leu2) in significantly greater numbers than $T$ helper lymphocytes (CD4/Leu3).

Bronchiolitis obliterans consisting of polypoid structures of loose myxoid connective tis-

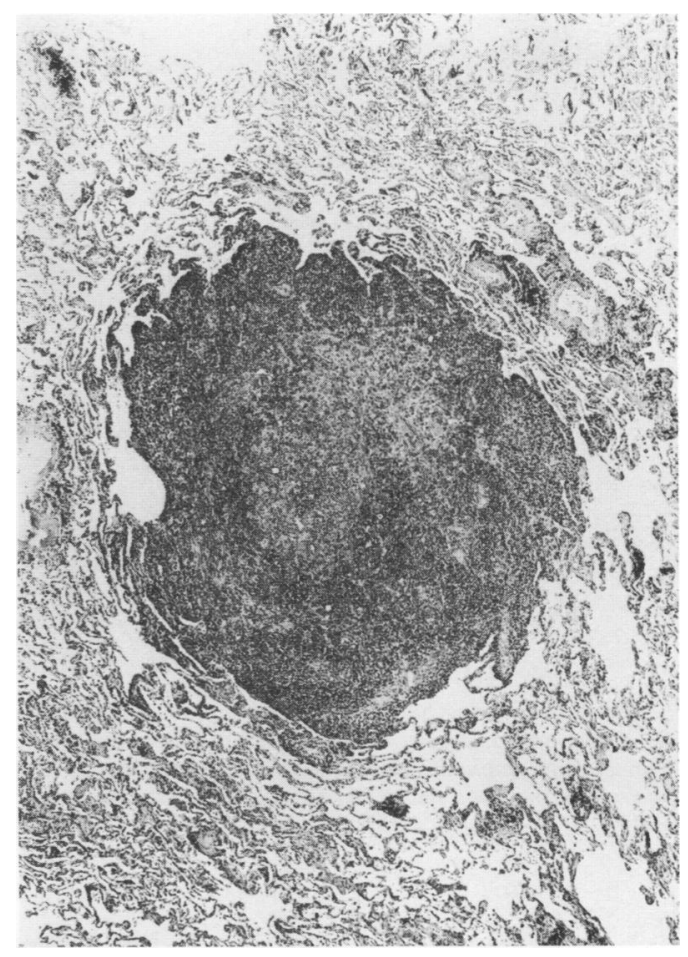

Figure 7 Hyperplastic bronchial associated lymphoid tissue (BALT) in open lung biopsy material from a 35 year old Haitian patient with lymphoid interstitial pneumonia and AIDS. Note the "crab-like" appearance of the lesion. Stain: haematoxylin and eosin. Original magnification $\times 80$ reduced to $53 \%$ in origination. Reproduced from ref 88 with permission.

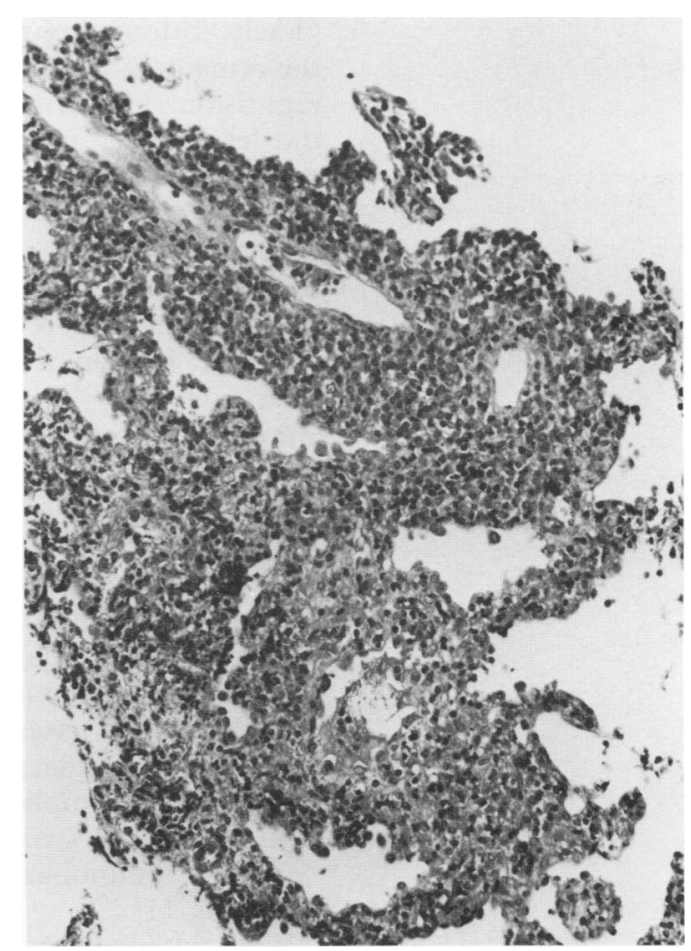

Figure 8 In this patient with AIDS and lymphoid interstitial pneumonia a diffuse infiltrate of lymphocytes and plasma cells was seen with marked widening of the pulmonary interstitium. Stain: haematoxylin and eosin. Original magnification $\times 120$ reduced to $53 \%$ in origination. Reproduced from ref 88 with permission. 

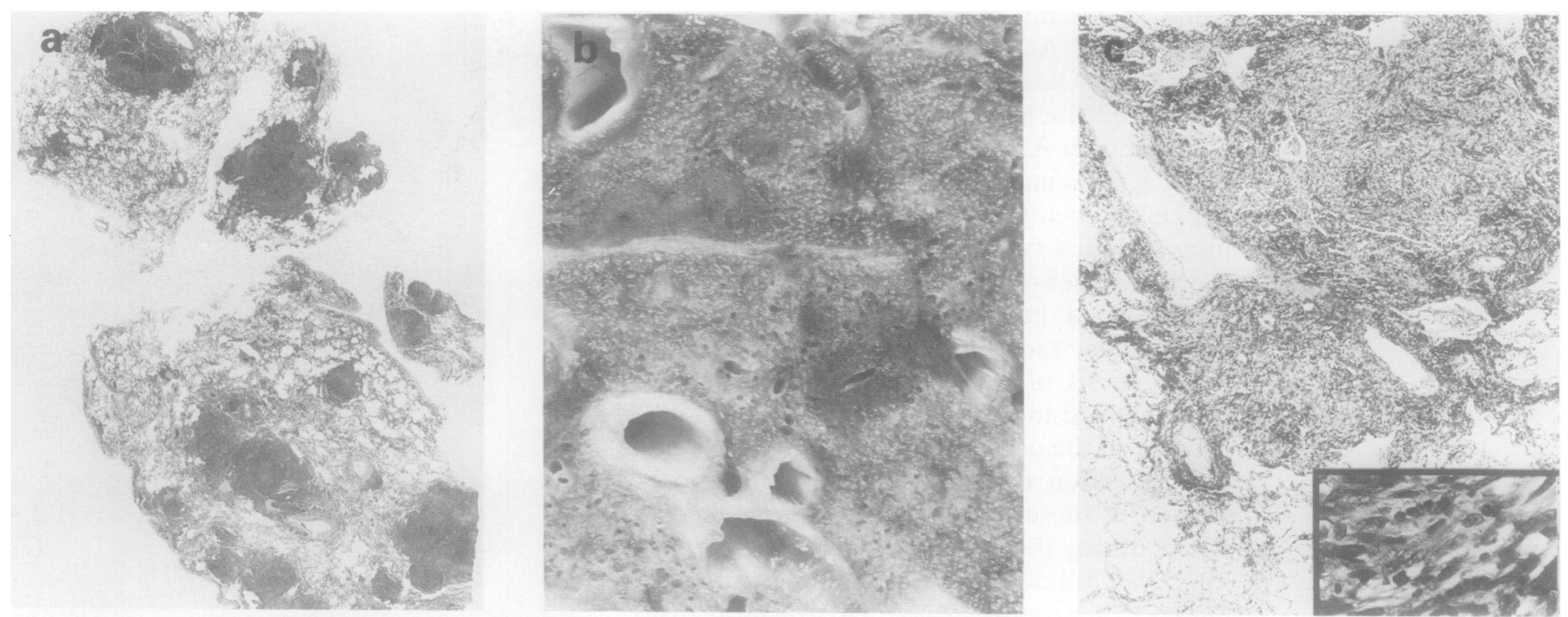

Figure 9 (a) Lung biopsy material from a 35 year old Haitian man with AIDS and lymphoid interstitial pneumonia (same case as in fig 7). (b) Gross appearance of the lung at postmortem examination in same patient one month later showing confluent, haemorrhagic and greyish areas representing lymphoid interstitial pneumonia lesions evolving into Kaposi's sarcoma. (c) Kaposi's sarcoma arising in prior lesion of lymphoid interstitial pneumonia in same patient. The inset shows characteristic spindle cell proliferation in same lung. Stain: haematoxylin and eosin. Original magnification $\times 40$ (a), $\times 80$ (c), $\times 750$ (inset) reduced to $43 \%$ in origination. Reproduced from ref 88 with permission.

sue occluding respiratory bronchioles was seen. Distally, there was atelectasis with accumulation of "foamy" histiocytes, a picture characteristic of "endogenous" lipid pneumonia. The presence of bronchiolitis obliterans was frequently seen in association with the most severe degrees of lymphoid interstitial pneumonia and probably accounts for the areas of alveolar disease.

The pathological evolution of lymphoid interstitial pneumonia from the time of diagnosis to death was studied in a group of eight adults and five children at post mortem examination. ${ }^{88}$ In three adults the process had resolved completely, in four it remained unchanged, and in the remaining patient it showed signs of slight regression. The striking nodular component of the lesions was markedly diminished or had vanished altogether in most children studied at post mortem. On the other hand, the diffuse component of lymphoid interstitial pneumonia remained unchanged in four patients and actually increased in one. In none of the patients, adults or children, was there evidence of diffuse interstitial fibrosis of the lung, but increased amounts of reticulin fibres and loose fibroblastic as well as capillary proliferation were present at sites of previously hyperplastic BALT.

Unusual associations of lymphoid interstitial pneumonia infected individuals include the remarkable transformation of infiltrates of lymphoid interstitial pneumonia into Kaposi's sarcoma in two cases (fig 9); the development of multiple vascular leiomyomas in one child (fig 10); and lymphocytic arteritis associated with plexiform structures and a picture of "primary" pulmonary hypertension in another adult (fig 11). ${ }^{88}$

The pathogenesis of lymphoid interstitial pneumonia remains to be clarified. The recovery of HIV from bronchoalveolar lavage fluid in these patients, as well as in situ hybridisation studies by Chayt et $a l^{107}$ and Travis et $a l^{108}$ support the role of this virus as the cause

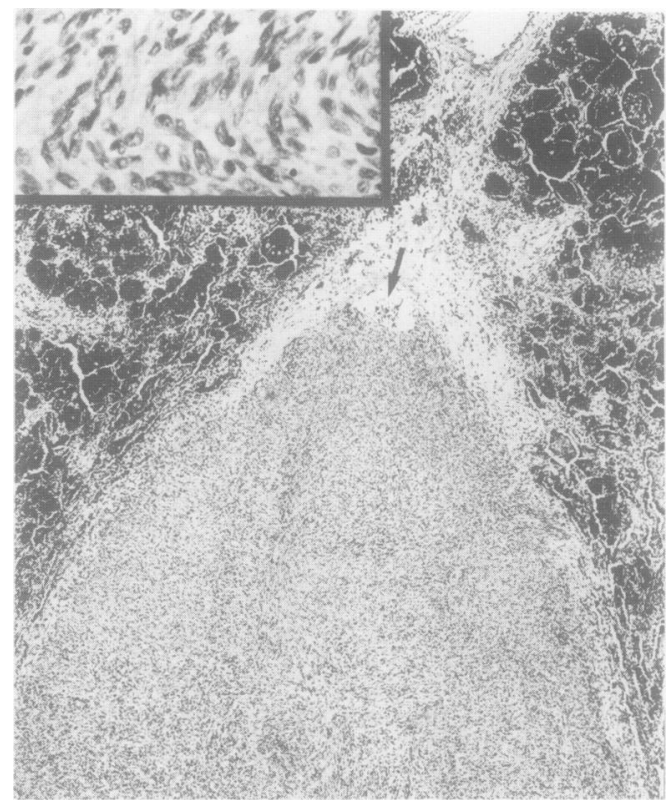

Figure 10 Lung of a child with AIDS, lymphoid interstitial pneumonia and peculiar leiomyoma arising in a pulmonary vein. The lumen of the vein is indicated by an arrow. The lesion is surrounded by alveolar haemorrhage. The inset shows the detail of the muscle proliferation which was positive for muscle specific antigen by the immunoperoxidase technique. Stain: haematoxylin and eosin. Original magnification $\times 80$ (inset $\times 750$ ) reduced to $59 \%$ in origination.

of lymphoid interstitial pneumonia. In five of our cases ${ }^{88}$ however, the presence of HIV was investigated by the avidin-biotin immunoperoxidase technique using p24 antibody (Du Pont Laboratories, Wilmington, Delaware, USA) in formalin fixed, paraffin embedded tissue, with negative results.

A second line of thinking suggests that, following infection of $T$ lymphocytes by HIV, Epstein-Barr virus (EBV) containing B lymphocytes proliferates leading to a polyclonal B cell population in the lungs and other tissues. The role of EBV in our patient population was investigated several times. ${ }^{88}$ Two of the seven 

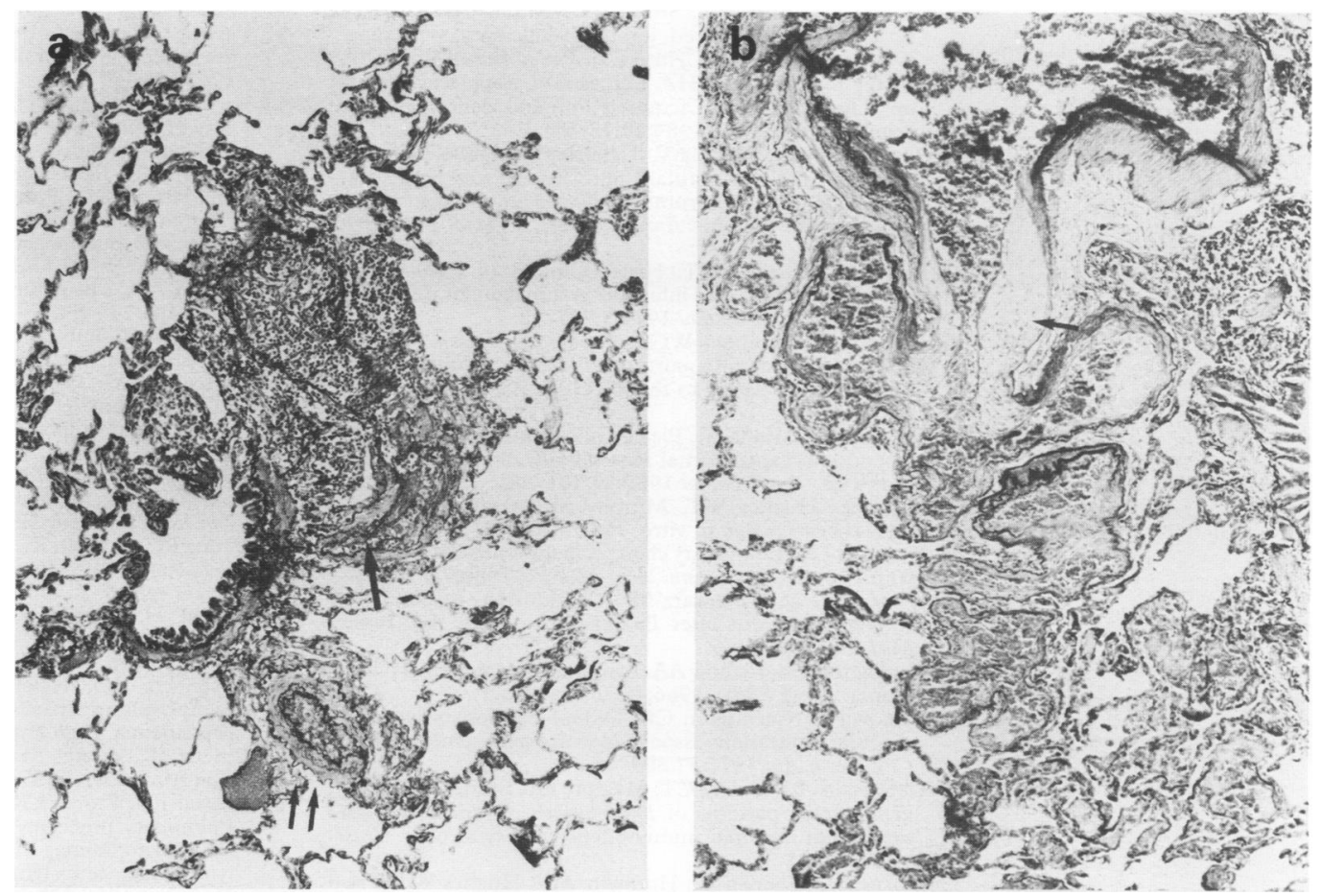

Figure 11 (a) Necrotising lymphocytic vasculitis in a young Haitian patient with AIDS, lymphoid interstitial pneumonia, and pulmonary hypertension. The arrow indicates the remains of the arterial wall, much of which is totally destroyed and infiltrated by lymphocytes. A muscular artery adjacent to a bronchiole shows marked medial hypertrophy (two arrows). (b) Same case as in (a) showing a well developed "plexiform" structure. The parent artery shows marked medial hypertrophy and a cushion of fibrous tissue at the origin of the "plexiform" lesion (arrow). Note the adjacent "dilatation" lesions and the absence of angiitis at this stage. Stain: elastic tissue. Original magnification $\times 80$ reduced to $57 \%$ in origination. Reproduced from ref 88 with permission.

children had negative serological evidence of prior EBV infection, a finding that mitigates strongly against a primary role for EBV. Only one child had serological evidence of acute infection at the time of diagnosis of lymphoid interstitial pneumonia. This child exhibited the most florid example of lymphoid proliferation, including germinal centres with tingible body macrophages in the lung and regional lymph nodes. In situ hybridisation of the lung biopsy material for EBV showed only a rare positive cell. Four adults in whom in situ hybridisation for EBV was carried out were negative. We conclude that, although HIV is probably the main cause of lymphoid interstitial pneumonia, it is also possible that in some patients EBV might be a coexistent factor in triggering the lymphoproliferative response. A possible link between lymphoid interstitial pneumonia and the HTLV-I or HTLV-II viruses has recently been suggested, but the results are still inconclusive. ${ }^{109}$

1 Connor RI, Ho DD. Etiology of AIDS: biology of human retroviruses. In: DeVita Jr V, Hellman S, Rosenberg SA Curran J, Essex M, Fauci AS, eds. AIDS: etiology, treatmen and prevention. 3rd edn. Philadelphia: JB Lippincott, 1992:13-38.

2 Haseltine WA. The molecular biology of HIV-1. In: DeVita Jr V, Hellman S, Rosenberg SA, Curran J, Essex M, Fauci AS, eds. AIDS: etiology, treatment and prevention. 3rd edn Philadelphia: JB Lippincott, 1992:39-59.

3. CDC. 1993 Revised classification system for HIV infection and expanded surveillance case definition for AIDS among adolescents and adults. MMWR 1992;41 (Mo RR 17).

4 Marolda J, Pace B, Bonforte RJ, Kotin NM, Robinowitz J, Kattan M. Pulmonary manifestations of HIV infections in children. Pediatr Pulmonol 1991;10:231-5.

5 Edman JC, Kovacs JA, Masur H, Santi DV, Elwood JH, Sogin ML. Ribosomal RNA sequence shows Pneumocystis carinii to be a member of the fungi. Nature 1988;334: carinit to
6 Vanek J, Jirovec O. Parisitäre Pneumonie. "Interstitielle" Plasmazellenpneumonie der Frühgeborenen verursacht durch Pneumocystis carinii. Zentralbl Bakteriol Hyg $[A]$ 1952;158: $120-7$.

7 Pitkin AD, Grant AD, Foley NM, Miller RF. Changing patterns of respiratory disease in HIV positive patients in a referral centre in the United Kingdom between 1986-7 a referral centre in the United Kingd

8 Masur H, Ognibene FP, Yarchoan R, Shelhamer JH, Baird $\mathrm{BF}$, Travis $\mathrm{W}$, et al. CD4 counts as predictors of opportunistic pneumonias in human immunodeficiency virus (HIV) infection. Ann Intern Med 1989;111:223-31.

9 Scott GB, Hutto C, Makuch RW, Mastrucci MT, O'Connor $\mathrm{T}$, Mitchell CD, et al. Survival in children with perinatally acquired human immunodeficiency virus type 1 infection. N Engl f Med 1989;321:1791-6.

10 Goodgame RW. AIDS in Uganda: clinical and social features. N Engl f Med 1990;323:383-9.

11 Kovacs JA, Hiemenz JW, Macher AM, Stover D, Murray HW, Shelhamer J, et al. Pneumocystis carinii: a comparison between patients with the acquired immunodeficiency syndrome and patients with other immunodeficiencies. Ann Inter Med 1984;100:663-71.

12 Mones JM, Saldana MJ, Oldham SA. Diagnosis of Pneumocystis carinii pneumonia. Roentgenographic-pathologic correlates based in fiberoptic bronchoscopy specimen from patients with the acquired immunodeficiency syndrome. Chest 1986;89:522-37.

13 Bedrossian CW. Ultrastructure of Pneumocystis carinii: a review of internal and surface characteristics. Semin Diagn Pathol 1989;6:212-37.

14 Shiota T. Simultaneous demonstration of cyst walls and intracystic bodies of Pneumocystis carinii in paraffin embedded lung sections using Gomori's methenamine silver bedded lung sections using Gomori's methenamine silver

15 Saldana MJ, Mones JM, Martinez GR. The pathology of treated Pneumocystis carinii pneumonia. Semin Diagn Pathol 1989;6:300-12.

16 Katzenstein AL, Bloor CM, Liebow AA. Diffuse alveolar damage. The role of oxygen, shock and related factors Am $\mathcal{F}$ Pathol 1976;85:210-22.

17 Askin FB, Katzenstein AL. Pneumocystis infection masquerading as diffuse alveolar damage. A potential source of diagnostic error. Chest 1981;79:420-2.

18 Weber WR, Askin FB, Dehner LP. Lung biopsy in Pneumocystis carinii pneumonia. A histopathologic study of typical and atypical features. Am f Clin Pathol 1977;67: 11-9.

19 Nash G, Fligiel S. Pathologic features of the lung in the acquired immune deficiency syndrome (AIDS). An autopsy study of seventeen homosexual males. Am f Clin Pathol 1984;81:6-12.

20 Welch K, Sinkbeiner W, Alpers CE, Blumenfeld W, Davis $\mathrm{RL}$, Smuckler EA. Autopsy findings in the acquired immune deficiency syndrome. $\mathcal{F} A M A$ 1984;252:1152-9. 
21 Guarda LA, Luna AA, Smith JL, Mansell PW, Gyorkey F, Roca AN. Acquired immune deficiency syndrome: post-mortem findings. Am 7 Clin Pathol 1984;81:549-57.

22 Mobley K, Rotterdam HZ, Lerner CW, Tapper ML. Autopsy findings in the acquired immune deficiency syndrome. Pathol Annu 1985;20:45-65.

23 Ramaswamy G, Jagadha V, Tchertkoff V. Diffuse alveolar damage and interstitial fibrosis in acquired immunodeficiency syndrome patients without concurren pulmonary infection. Arch Pathol Lab Med 1985;109. 408-12.

24 Price RA, Hughes WT. Histopathology of Pneumocystis carinii infestation and infection in a malignant disease in childhood. Hum Pathol 1974;5:737-52.

25 Barton EG Jr, Campell WG Jr. Pneumocystis carinii in lungs of rats treated with cortisone acetate. Ultrastructural observations relating to the life cycle. Am $\mathcal{f}$ Pathol 1969; observations

26 Lanken PN, Minda M, Pietra GG, Fishman AP. Alveolar response to experimental Pneumocystis carinii pneumoni in the rat. Am F Pathol 1980;99:561-88.

27 Pifer LL, Hughes WT, Murphy MJ Jr. Propagation of Pneumocystis carinii in vitro. Pediatr Res 1977;11:305-16.

28 Nowak J. Late pulmonary changes in the course of infection with Pneumocystis carinii. Acta Med Pol 1966;7:23-41.

29 Whitcombe ME, Schwarz MI, Charles MA, Larson, PH. Interstitial fibrosis after Pneumocystis carinii. Ann Intern Med 1970;73:761-5.

30 Carrington CB, Liebow AA. Lymphocytic interstitial pneumonia. Am f Pathol 1966;48:36a (abstract).

31 Liebow AA, Carrington CB. Diffuse pulmonary lymphoreticular infiltrations associated with dysproteinemia. Me Clin North Am 1973;57:809-43.

32 DeLorenzo LJ, Huang CT, Maguire GP, Stone DJ. Roentgenographic patterns of Pneumocystis carinii in 104 patients with acquired immunodeficiency syndrome. Chest 1987;91:323-7.

33 Stokes DC, Shenep JL, Horowitz ME, Hughes WT. Presentation of Pneumocystis carinii pneumonia as unilateral hyperlucent lung. Chest 1988;94:201-2.

34 Milligan SA, Stulberg MS, Gamsu G, Golden JA. Pneumocystis carinii pneumonia radiographically simulating mocystis carinit pneumonia radiographically simulat

35 Cross AS, Steigbigel RT. Pneumocystis carinii pneumonia presenting as localized nodular densities. $N$ Engl f Med 1974;291:831-2.

36 Rodriguez-Servera RJ, Altieri PI, Castillo M. Unusua roentgenographic manifestation of Pneumocystis carinii pneumonia. Chest 1976;69:422-3.

37 Hartz JW, Geislinger KR, Scharyj M, Muss HB. Granulomatous pneumocystosis presenting as a solitary pulmonary nodule. Arch Pathol Lab Med 1985;109:466-9.

38 Bier S, Krevisky B, Loenidas J. Pneumocystis carinii pneumonia preser.

39 Barrio JL, Suarez M, Rodriguez JL, Saldana MJ, Pitchenik AE. Pneumocystis carinii pneumonia presenting as caAE. Pneumocystis carinii pneumonia presenting as cavitating and noncavitating solitary pulmonary nodules in patients with the acquired immunode

40 Bleiweiss IJ, Jagirdar JS, Klein MJ, Siegel JL, Krelenstein DJ, Gribetz AR, et al. Granulomatous Pneumocystis carinii pneumonia in three patients with the acquired immune deficiency syndrome. Chest 1988;94:580-3.

41 Cruickshank B. Pulmonary granulomatous pneumocytosis following renal transplantation. Am $\mathcal{F}$ Clin Pathol 1975; 63:384-90.

42 Blumenfeld W, Basgoz N, Owen WF Jr, Schmidt DM. Granulomatous pulmonary lesions in patients with the acquired immunodeficiency syndrome (AIDS) and Pneumocystis carinii infection. Ann Intern Med 1988;109:505-7.

43 Eng RHK, Bishburg E, Smith SM. Evidence for destruction of lung tissue during Pneumocystis carinii infection. Arch of lung tissue during Pneum

44 Case records of the Massachusetts General Hospital (case 9-1989). N Engl f Med 1989;320:582-7.

45 Liu YC, Tomashefski JF Jr, Tomford JW, Green H. Necrotizing Pneumocystis carinii vasculitis associated with lung necrosis and cavitation in a patient with acquired immunodeficiency syndrome. Arch Pathol Lab Med 1989; 113:494-7.

46 Saldana MJ, Mones JM. Cavitation and other atypical manifestation of Pneumocystis carinii pneumonia. Semin Diagn Pathol 1989;6:273-86.

47 Travis WD, Pittaluga S, Lepschek GY, Pgmobeme FP, Suffredini AF, Masur H, et al. Atypical pathologic manifestations of Pneumocystis carinii pneumonia in the acnifestations of Pneumocystis carinii pneumonia in the acquired immune deficiency syndrome. Review of 123 lung biopsies from 76 patients with emphasis on cysts, vascular invasion, vasculitis,

48 Murry CE, Schmidt RA. Tissue invasion by Pneumocystis carinii: a possible cause of cavitary pneumonia and pneumothorax. Hum Pathol 1992;23:1380-7.

49 Barnett RN, Hull JG, Vortel V, Schwarz J. Pneumocystis carinii in lymph nodes and spleen. Arch Pathol 1969;88: $175-80$.

50 Schinalla RA, Breda SD, Hammerschlag PE. Otic infection due to Pneumocystis carinii in an apparently healthy man with antibody to the human immunodeficiency virus. Ann Intern Med 1987;106:399-400.

51 Coulman CU, Greene I, Archibald RWR. Cutaneous pneumocystosis. Ann Intern Med 1987;106:396-8.

52 Awen CF, Baltzan MA. Systemic dissemination of Pneumocystis carinii pneumonia. Can Med Assoc f 1971;104:
809-12.

53 Pavlica F. The first observation of congenital Pneumocystis pneumonia in a fully developed stillborn child. Ann Pediatr 1962;198:177-84.

54 Kwok S, O'Donnell JJ. Retinal cotton-wool spots in a patient with Pneumocystis carinii infection. N Engl f Med 1982;307:184-5.

55 Macher AM, Bardenstein DS, Zimmerman LE, Steigman CK, Pastore L, Poretz DM, et al. Pneumocystis carini choroiditis in a male homosexual with AIDS and disseminated pulmonary and extrapulmonary $P$ carinii infection. $N$ Engl $\mathcal{Y}$ Med 1987;316:1092.

56 Macher AM. The pathology of AIDS. Public Health Reports 1988;103:246-54

57 Unger PA, Rosenblum M, Krown SE. Disseminated Pneumocystis in patient with AIDS. Hum Pathol 1988;19:113-6.

58 Carter TR, Cooper PH, Petri WA Jr, Kim CK, Walzer PD, Guerrant RL. Pneumocystis carinii infection of the small intestine in a patient with acquired immune deficiency syndrome. Am 7 Clin Pathol 1988;89:679-83.

59 Montes M, Tomasi TB, Noehren TH, Culver GJ. Lymphoid interstitial pneumonia with monoclonal gammopathy. Am Rev Respir Dis 1968;98:277-80.

60 Young RC, Tillman RL, Burton AF, Sampson CC. Lymphoid interstitial pneumonia with polyclonal gammopathy: a case report. $\mathcal{F}$ Natl Med Assoc 1969;61:310-4

61 Moran TJ, Totten RS. Lymphoid interstitial pneumonia with dysproteinemia: report of two cases with plasma cell predominance. Am $\mathcal{F}$ Clin Pathol 1970;54:747-56.

62 Greenberg SD, Haley MD, Jenkins DE, Fischer SP. Lymphoplasmacytic pneumonia with accompanying dysproteinemia. Arch Pathol 1973;96:73-80.

63 Binette JP, Montes M. Lymphoid interstitial pneumonia. Can Med Assoc ₹ 1976;114:810-2.

64 Julsrud PR, Brown LR, Li CY, Rosenow EC, Crowe JK. Pulmonary processes of mature-appearing lymphocytes: Pulmonary processes of mature-appearing lymphocytes: pseudolymphoma, well-differentiated lymphocytic lymphoma, and lymphocy

65 Strimlan CV, Rosenow EC, Weiland LH, Brown LR Lymphocytic interstitial pneumonitis: review of thirteen cases. Ann Intern Med 1978;88:616-21.

66 Church JA, Isaacs H, Saxon A, Keenst G, Richards W. Lymphoid interstitial pneumonitis and hypogamma-
globulinemia in children. Am Rev Respir Dis 1981;124: 491-6.

67 Kohler PF, Cook RD, Brown WR, Manguso RL. Common variable hypogammaglobulinemia with $\mathrm{T}$-cell nodular lymphoid interstitial pneumonitis and B-cell nodular lymphoid hyperplasia: different lymphocyte populations with a similar response to prednisone therapy. $\mathcal{f}$ Allergy with a similar response to prednin

68 Yoshizawa Y, Ohdama S, Ideda A Ahtsuka R, Masuda S Tanaka $M$. Lymphoid interstitial pneumonia associated Tanaka $M$. Lymphoid interstitial pneumonia associated with depressed cellular immunity and polyclo

69 Case records of the Massachusetts General Hospital (case 38-1977). N Engl f Med 1977;297:652-60.

70 Weisbrot IM. Lymphomatoid granulomatosis of the lun associated with a long history of benign lymphoepithelial lesions of the salivary glands and lymphoid interstitia pneumonitis: Report of a case. Am $\mathcal{f}$ Clin Pathol 1976 66:792-801.

71 Bonner H, Ennis RS. Lymphoid infiltration and amyloidosis of lung in Siogren's syndrome. Arch Pathol 1973, $95: 42-4$

72 Faguet GB, Webb HH, Agee JF, Ricks WB. Immunologically diagnosed malignancy in Sjogren's pseudomunologically diagnosed malignancy in

73 Weissman $\mathrm{E}$, Becker $\mathrm{NH}$. Interstitial lung disease in primary biliary cirrhosis. Am $\mathcal{f}$ Med Sci 1983;385:21-7.

74 Levinson AI, Hopewell PC, Stites DP, Spitler LE, Fudenberg HH. Coexistent lymphoid interstitial pneumonia, pernicious anemia, and agammaglobulinemia: comment on autoimmune pathogenesis. Arch Intern Med 1976;136:213-6.

75 Helman CA, Keeton GR, Binatar SR. Lymphoid interstitia pneumonia with associated chronic active hepatitis and renal tubular acidosis. Am Rev Respir Dis 1977;115:161-4

76 Perrault C, Cousineau S, D'Angelo G, Gyger M, Nepveu F, Boileau J, et al. Lymphoid interstitial pneumonia after allogenic bone marrow transplantation: a possible manifestation of chronic graft-versus host disease. Cancer 1985;55:1-9.

77 O'Brodovich HM, Moser MM, Lu L. Familiar lymphoid interstitial pneumonia: a long term follow up. Pediatrics 1980;65:523-8.

78 Colby TV, Carrington CB. Lymphoreticular tumors and infiltrates of the lung. Pathol Annu 1983;18:27-79.

79 Colby TV, Carrington CB. Pulmonary lymphomas: current concepts. Hum Pathol 1983;14:884-7.

80 Jefferson M, Riddoch D, Smith WT. Fatal encephalopathy complicating lymphoid interstitial pneumonia. $\mathcal{f}$ Neurol complicating lymphoid interstitial p

81 Gibbs AR, Seal RME. Primary lymphoproliferative conditions of the lung. Thorax 1978;33:140-52.

82 Halprin GR, Ramirez JR, Pratt PC. Lymphoid interstitial pneumonia. Chest 1972;62:418-23.

83 Valeyre D, Amouroux J, Schmitt-Hausman I, Batesti JP. Pneumopathies interstitielles à lymphocyte et lymphomes pulmonaires primitifs: diagnostic differentiel. Presse Med 1985;14:1787-9.

84 Herbert A, Walters MT, Cawley MID, Godfrey RC. Lymphocytic interstitial pneumonia identified as lymphoma of mucosa associated lymphoid tissue. $\mathcal{F}$ Pathol 1984 ; 146:129-38. 
85 Banerjee D, Ahmad D. Malignant lymphoma complicating lymphocytic interstitial pneumonia: a monoclonal B-cell neoplasm arising in a polyclonal lymphoproliferative disneoplasm arising in a polyclonal lym

86 Verhamme M, Wynants P, Van de Woestijne KP, Lauweryns $\mathrm{J}$. Lymfoide interstitiele pneumonie: presentatie van twee gevallen met follow-up. Acta Clin Belg 1982;37:65-71.

87 Saldana MJ, Mones J, Buck BE. Lymphoid interstitial pneumonia in Haitian residents of Florida. Chest 1983; 84:347.

88 Saldana MJ, Mones JM. Lymphoid interstitial pneumonia in HIV infected individuals. Prog Surg Pathol 1992;12: 181-215.

89 Oleske J, Minnefor A, Cooper R Jr, Thomas K, de la Cruz $\mathrm{A}$, Ahdieh $\mathrm{H}$, et al. Immune deficiency syndrome in A, Ahdieh $\mathrm{H}$, et al. Immune defici

90 Rubinstein A, Sicklick M, Gupta A, Bernstein L, Klein N, Rubinstein E. Acquired immunodeficiency with reversed $\mathrm{T} 4 / \mathrm{T} 8$ ratios in infants born to promiscuous and drugaddicted mothers. $\mathcal{F A M} A$ 1983;249:2350-6.

91 Kradin RL, Mark EJ. Benign lymphoid disorders of the lung with a theory regarding their development. Hum Pathol 1983;14:857-67.

92 Joshi VV, Oleske JM, Minnefor AB, Saad S, Klein KM, Singh $\mathbf{R}$, et al. Pathologic pulmonary findings in children Singh $\mathrm{R}$, et al. Pathologic pulmonary findings in children with the acquired immunodeficiency synd

93 Joshi VV, Oleske JM, Saad S, Connor EM, Rapkin RH, Minnefor AB. Pathology of opportunistic infections in children with acquired immune deficiency syndrome. Pediatr Pathol 1986;6:145-50.

94 Joshi VV, Oleske JM. Pulmonary lesions in children with the acquired immunodeficiency syndrome: a reappraisal based on data in additional cases and follow-up study of previously reported cases. Hum Pathol 1986;17:641-2.

95 Joshi VV, Kauffman S, Oleske JM, Fikrig S, Denny T, Gadol C, et al. Polyclonal polymorphic B-cell lymphoproliferative disorder with prominent pulmonary involvement in children with acquired immune deficiency syndrome. Cancer 1987;59:1455-62.

96 Joshi VV. Pathology of AIDS in children. Pathol Annu 1989;1:355-81.

97 Scott GB, Buck BE, Leterman JG, Bloom FL, Parks WP
Acquired immunodeficiency syndrome in infants. $N$ Engl f Med 1984;310:76-81

98 Marchevsky A, Rose MD, Chrystal G, Kleinerman J. Pulmonary complications of the acquired immunodeficiency syndrome: a clinico-pathologic study of 70 cases. Hum Pathol 1985;16:659-70.

99 Solal-Celigny P, Couderc LJ Herman D, Herve P SchaffarDeshayes L, Brun-Vezinet F, et al. Lymphoid interstitial Deshayes $\mathrm{L}$, Brun-Vezinet $\mathrm{F}$, et al. Lymphoid interstitial pneumonitis in acquired immunodeficiency syndrome-

100 Grieco MH, Chinoy-Acharya P. Lymphocytic interstitial pneumonia associated with the acquired immune-deficiency syndrome. Am Rev Respir Dis 1985;131:952-5.

101 Rubinstein A, Morecki R, Silverman B, Charytan M, Krieger BZ, Andiman W, et al. Pulmonary disease in children with acquired immune deficiency syndrome and AIDS-related complex. 7 Pediatr 1986;108:498-503.

102 Couderc LJ, Herve P, Solal-Celigny P, Herman D, D'Agay $\mathrm{MF}$, Morinet $\mathrm{F}$, et al. Pneumonie lymphoide interstitielle et polyadenopathies chez des sujets infectes par le virus et polyadenopathies chez des sujets infectes par
LAV/HTLV III. Presse Med 1986;15:1127-30.

103 Morris JC, Rosen MJ, Marchevsky T, Tierstein AS. Lymphocytic interstitial pneumonia in patients at risk for the acquired immune deficiency syndrome. Chest 1987;91 63-7

104 Teirstein AS, Rosen MJ. Lymphocytic interstitial pneumonia. Clin Chest Med 1988;9:467-71.

05 Anderson VM, Lee H. Lymphocytic interstitial pneumonitis in pediatric AIDS. Pediatr Pathol 1988;8:417-21.

106 Lin RY, Gruber PJ, Saunders R, Perla EN. Lymphocytic interstitial pneumonitis in adult HIV infection. NY State f Med 1988;88:273-6.

107 Chayt KJ, Harper ME, Marselle LA, Lewin EB, Rose RM Oleske JM, et al. Detection of HTLV-III RNA in lungs of patients with AIDS and pulmonary involvement. $₹ A M A$ 1986;256:2356-9.

108 Travis WD, Fox CH, Devaney KO, Weiss LM, O'Leary TJ, Ognibone FP, et al. Lymphoid pneumonitis in 50 adult patients infected with the human immunodeficiency virus. Hum Pathol 1992;27:529-41.

109 Courderc LJ, Matheron S, Clauvel JP, Caubarrere I, De granges C. Detection of HTLV-1 or HTLV-2 in HIV infected patients with lymphoid interstitial pneumonia. Int Conf AIDS 1991;7:217. 